\title{
NARROW GATE? THE PROCESS OF ENTERING INTERNATIONAL AND EU AGREEMENTS INTO THE CONSTITUTIONAL ORDER OF AN EU MEMBER STATE: THE EXAMPLE OF THE CZECH REPUBLIC ${ }^{+}$
}

\author{
Jan Kysela, * Pavel Ondrejek ${ }^{* *}$ and Jana Ondrejkova ${ }^{* * *}$
}

Summary: The aim of this article is to illustrate various pitfalls which must be dealt with before an international agreement may begin to function, ie before it creates a legal obligation upon a contracting state. The Czech Republic is, according to the authors, an appropriate example to illustrate this, for various reasons, as it is an EU Member State with a (prevailing) parliamentary form of governance and a (rather complex) bicameral parliament.

In the first place, the authors deal with the historical and comparative context of the ratification procedure of international agreements in the Czech Republic. Since this procedure in every country involves the interplay of several bodies, a proper evaluation of the historical context may help in the interpretation of constitutional regulation, which is rather brief in the Czech Republic. One of the main questions of the ratification procedure, which the authors address, is the role of the president of the Czech Republic in the procedure of the ratification of international agreements. On the basis of the historical and the current constitutional regulation, the authors conclude that the competence of the president related to international agreements cannot be considered to be his/her prerogative. The president's act of ratification is, according to the authors, the formal conclusion of an internal consultation procedure on an international agreement in the Czech Republic. In exercising this competence, the president is endowed with a very limited margin of discretion.

The authors furthermore make a comparative study based on a questionnaire circulated via the European Centre for Parliamentary Research and Documentation on the role of the government, parliament and the head of state in the ratification procedure of international treaties.

\footnotetext{
The article was written under grant project No P408/10/1599 'Methodology of interpretation of law as a guarantee for legal certainty in the modern democratic state based on the rule of law'.

Associate Professor, Department of Political Science and Sociology, Faculty of Law, Charles University in Prague.

** PhD candidate, Faculty of Law, Charles University in Prague.

*** Lecturer, Department of Political Science and Sociology, Faculty of Law, Charles University in Prague.
} 
The main part of the article deals with selected problems and possible solutions of the negotiation procedure of international agreements and the practice of application (namely the provisional application of international treaties, the classification of international treaties, repeated submissions of the proposal on the expression of consent with the ratification of an international treaty by chambers of parliament, simplified parliamentary approval for the ratification of presidential treaties, and the concept of ratification).

The article ends with brief observations regarding international treaties concluded by the European Union or the Union together with the Member States, the significance of which will probably continue to increase.

\section{Introduction}

A significant concern of both international and European law doctrine is quite naturally focused on the effects that 'classical' international agreements exert on the legal orders of signatory states or EU Member States. This would also include agreements concluded by the European Union, or among other contracting parties by the European Union. Our aim is to present various pitfalls which must be dealt with before an agreement may begin to function, ie before it creates a legal obligation upon the contracting state. The Czech Republic is an appropriate example to illustrate this for various reasons, as it is an EU Member State with a (prevailing) parliamentary form of governance and a (more complex) bicameral parliament. The relationship between international law and the Czech Republic's constitution is deeply rooted in history, going back to 1920 when the first definitive constitution of the Czechoslovak Republic was adopted. Even if the current Czech constitution was amended due to accession to the EU several years ago, it still remains incomplete. It presents various problems to resolve, which more than likely will be encountered in other states as well.

At the same time, the Czech Republic may be considered somewhat atypical because the formal status of its head of state is slightly stronger than usually encountered in parliamentary republics. The well-established tradition of high public respect for the office of the Czech president also plays an important role. ${ }^{1}$ A combination of these factors with a politically strong head of state with pronounced opinions may result in the Czech Republic taking the spotlight, as occurred during the dramatic process of the ratification of the Lisbon Treaty.

\footnotetext{
1 See J Kysela and Z Kühn 'Presidential Elements in Government: The Czech Republic'
} (2007) 1 European Constitutional Law Review 91. 


\section{Insufficient constitutional foundation - problems in disputes between constitutional actors}

As concerns international law, the Czechoslovak constitutions from 1918 (the first provisional constitution) until the end of the existence of the Czechoslovak state were slightly elaborated over time, which reflected the constitution's growing importance. This is also true of the current constitution, in force since 1 January 1993 and in which article 1 paragraph 2 (the basis for the functioning of general international law) and article 10a (authorisation for the transfer of competences in particular to the EU) were added to the amended articles 10 and 49 (the status of international agreements in the legal order). Other provisions of the constitution were affected as well. Perhaps somewhat paradoxically, the central competence provision, ie the president's power to conclude and ratify international agreements, has remained the same. The provision of the constitution reads:

The president of the republic: a) represents the state externally, b) concludes and ratifies international agreements; the president may transfer the conclusion of international agreements to the government or to its particular members with its consent.

The constitutional charter from 1920, as opposed to the provisional constitution from 1918, extracted the contractual competence from the general state representation competence. Since that time, the text has not changed to a great extent. What did change in our view, however, was the context and, as a result, the meaning.

This is the classical problem of the adaptation of unchanged texts and institutions which is connected with the need for evolutional change in the 'pre-understanding' of the concerned actors and interpreters, ie, their understanding of an old text in changing contexts (the changing role of international law in the international community as well as in the Czech Republic, shifts in the competences of other constitutional bodies, etc). Besides, one person may understand the same provision or clause as forming part of the prerogatives of the head of state, while another person attributes to it the function of identifying the body which finalises the process of the assumption of international obligations, but in reality the assumption has already been decided by someone else. In this instance, when disagreement occurs at the starting point of interpretation, a fragmentary and changeless constitutional regulation becomes a disadvantage.

Labelling it a 'disadvantage' may not be entirely correct, since it is connected with different types of emerging problems and ways they are resolved in constitutional law. We can, for instance, say that the reality of the assumption of international obligations differs significantly from the 
text of the constitution, since it is dominated by the government and not by the President of the Republic. In the Czech Republic, this situation is also rather similar to the procedure for the nomination of judges, which rests formally in the hands of the president, yet is in fact dominated by the Ministry of Justice. Such divergence can occur as long as all bodies concerned adhere to the standing practice. If, however, someone starts reverting to the constitutional text, or possibly interprets the constitution in an unexpected manner ('It is I, therefore it is my will, that is to be projected in the conclusions, ratification, nomination...'), he breaks the consensus on which the practice has been built. The outcome can be: a) general acceptance of the new definition of the roles (reformulation of the Hartian rule of recognition); b) stalemate (dissonance leads to mutual blocking); c) legislative intervention; d) calling for a neutral arbiter - an authoritative interpreter.

In the last mentioned case, a change occurs in the model of governance in the defined group of relations, from the dyadic model, characterised by two parties arguing (as in a tug-of-war) between themselves, into a triadic model with the arbiter standing above the parties. ${ }^{2}$ In our situation, this practically means judicialisation, here most probably on the basis of a conflict of competences. If judicial proceedings are not brought about, or if such a procedural tool is not available, a new practice, or a differently interpreted one, may arise - in short, a constitutional convention that will have to be taken into account in the interpretation of constitutional relations and institutes. Each of the actors must take into account that not only his action, but also his inaction, 'can be used against him' ${ }^{3}$

\footnotetext{
2 M Shapiro and A Stone Sweet, On Law, Politics and Judicialization (OUP 2002) 15.

3 A Heard distinguishes the absence of a precedent and a negative precedent. In the former case, the occasion to act did not occur (eg to decide on a state of emergency) so we can hardly draw any relative conclusions. In the latter case, action in a specific manner was not taken, and as such an action was felt to be inconsistent with a constitutional principle. See A Heard, Canadian Constitutional Conventions: The Marriage of Law and Politics (OUP 1991). In relation to our topic, this means that we will not find in practice how it is with the exercise of the power to ratify international treaties as long as the president ratifies them, because he intends to do so. Only after he refuses to ratify will we deal with the relevance and consequences of his (un)willingness. An important factor is the reaction of others who may become reconciled with the possible refusal (postponement) of the ratification, or may take political and legal actions expressing their disagreement. Should others abstain from anything and the president finally 'successfully' not ratify, in the long term or repeatedly, we can hardly ignore this fact when interpreting the constitution. In this sense, $Z$ Koudelka points out the long-lasting non-ratification of the additional protocol to the European Social Charter - does the inaction of the government mean assenting to the opinion that the president is entitled to postpone or refuse ratification? See $Z$ Koudelka, 'Prezident a mezinárodni smlouvy' [President and International Treaties] (2009) 9 Právník 937-938.
} 


\section{General remarks on the division of roles in the conclusion of in- ternational treaties}

The traditional starting point for the division of roles in the process of concluding international treaties is the well-known thesis according to which foreign policy is 'the province of Princes, not of commoners'. ${ }^{4}$ Historically, it concerns the prerogative of heads of state, the real administration of which is usually in the hands of the government (we refer to the parliamentary form of governance). In the course of time, those who started to intervene in the origination of international obligations alongside executive power were parliaments.

One of the preconditions was the distinction between the subject possessing the treaty-making capacity (the sovereign, but also the estates in the Estate's monarchy), and the body endowed with treaty-making power (the monarch or his assignee as the representative of a contracting party). ${ }^{5}$ This distinction, coupled with control of whether 'a plenipotentiary who had negotiated and signed a treaty in fact acted within the scope of his full powers', ${ }^{6}$ moved from the end of the $18^{\text {th }}$ century to a level where 'the requirement of ratification gives the legislature a degree of control over the exercise of treaty-making power by the executive'. ${ }^{7}$ Concise clauses in the first constitutions, often inspiring one another, were consecutively modified by varied developments and by the practice of state bodies.

An important aspect for the inclusion of parliaments in concluding international treaties also arises from the subsequent status of international treaties in the domestic legal order. Therefore, for example in countries with a dualistic approach, the weak position of parliament in the ratification procedure can be compensated for by its impact on the internal implementation of the international treaties in the form of laws. In any event, this represents a combination of the controlling (and legitimising) role and the law-making role.

Traditionally, several categories of international treaties commonly requiring the consent of parliament have been developed: treaties introducing a financial burden on the budget or those that change the state

\footnotetext{
4 B Ehrenzeller, Legislative Gewalt und Aussenpolitik (Helbing \& Lichtenhahn, 1993) V.

5 For details on the historical development of specific theories, see P Haggenmacher 'European Origins of Legislative Participation' in SA Riesenfeld and FM Abbott (eds), Parliamentary Participation in the Making and Operation of Treaties (Martinus Nijhoff Publishers 1994) $19 \mathrm{ff}$.

6 Council of Europe, British Institute of International and Comparative Law, Treaty Making: Expression of Consent by States to be Bound by a Treaty (Kluwer Law International 2001) 11.

7 ibid.
} 
borders, ${ }^{8}$ treaties about war and peace, etc. ${ }^{9}$ Furthermore, in some states a general requirement exists for parliaments to give their consent to any international treaties, while only certain exceptions are recognised. ${ }^{10}$ Today, above all, the involvement of parliaments raises the question of a search for balance between the efforts of the executive branch to carry out effective and efficient foreign policies and the requirement for parliamentary supervision of these policies (the form of governance can be a significant variable).

From a chronological perspective, the particular ways of parliament involvement can be divided into three phases: the initiating and negotiating phase, the phase concerning approval or ratification of the treaty, and the phase after the treaty has entered into force. ${ }^{11}$

During the initiatory and negotiation phase, a settled practice of informal consultation of parliament by the executive may exist, despite the fact that explicit regulation is lacking. Moreover, a broader consultation of the persons concerned takes place in a situation where the conclusion of a particular treaty could influence the outcome of upcoming elections. ${ }^{12}$ The advantage of this approach is that the treaty's proposed wording will reflect the comments of members of parliament that could otherwise hinder its approval, should these comments be made after the text has been finalised. The extensive involvement of the people's representatives in the conclusion of treaties having important nationwide significance can, at the same time, increase their legitimacy. ${ }^{13}$ On the other hand, we must realise that individual members of parliament usually do not possess the expertise needed for the formulation of the treaties' wording and it might be more effective for them to merely comment on the prospective treaty's provisions.

In the phase of the conclusion of an international treaty, the extent of the involvement of parliaments differs from one state to another: starting with the concept of the tacit consent of parliament if certain conditions are met, ${ }^{14}$ through the option of the parliament only to give consent to a treaty or to refuse it, to the powers of parliament to set conditions

\footnotetext{
8 Compare, eg, the provisions of the Sardinian and then Italian Constitution of 1848. See G Bognetti 'The Role of the Italian Parliament in the Treaty-Making Process' in Riesenfeld and Abbott (n 5) 90.

9 Council of Europe (n 6) 63.

10 P Van Dijk and BG Tahzib 'Parliamentary Participation in the Treaty-Making Process in the Netherlands' in Riesenfeld and Abbott (n 5) 115.

11 For more details, see Riesenfeld and Abbott (n 5) $7 \mathrm{ff}$.

12 Lord Templeman 'Treaty-Making and the British Parliament' in Riesenfeld and Abbott ( $\mathrm{n}$ 5) 163.

13 Another known, but, except for some changes in the European law, rarely used tool is the ratification referendum. See HC Scheu, Úvod do mezinárodního práva veřejného [Introduction to the Public International Law] (Auditorium 2010) 39.

14 Riesenfeld and Abbott (n 5) 119.
} 
requiring a reservation, declaration, or an interpretative explanation to be attached to the treaty. Separate issues consist in whether the authorised body is duty bound to ratify the treaty to which parliamentary assent was granted.

In addition, even after giving assent to an international treaty, parliament can have a direct or indirect impact on its application. Primarily, there is a link to the relationship between international and domestic laws and the status of international treaties in the domestic legal order, ie whether parliament can limit or eliminate the application of the international treaty by subsequent legal regulations. Furthermore, in some partially monistic systems, parliament influences the subsequent effects of the treaty in the domestic legal order by the chosen procedure for approval. ${ }^{15}$ Indirect interferences are also conceivable via the distribution of budgetary resources. There is, however, a far-reaching issue: whether the assent of parliament is also needed for the termination of the application of an international treaty requiring parliamentary approval for its entry into force.

\section{A brief comparison of the legal regulations of the competences of participants in the ratification process}

Current international law is a dynamic system that has expanded into many areas of regulation since the mid $20^{\text {th }}$ century. ${ }^{16}$ For this reason, we consider it useful to explore different models of involvement of state bodies in the process of ratifying international treaties, ie the most important source of international law. The aim is to describe the differences between foreign regulations, especially in comparison with Czech practice. Priority is given to democratic states with a civil law tradition. ${ }^{17}$

We proceed from our research executed in the form of a questionnaire addressed to ECPRD ${ }^{18}$ correspondents. The results were checked aga-

\footnotetext{
15 See, for example, art 86 lit d) of the Slovak constitution, according to which it belongs to the competences of parliament to decide whether a particular international treaty will have primacy in application according to art 7 para 5 of the constitution of the Slovak Republic. Before the so-called 'Euro-amendment' of the Czech constitution in 2001, effective qualification of the subsequent status of the treaty within the national legal order (only treaties on fundamental rights could have direct effect and be applicable over conflicting national law) was also under the competence of parliament, more precisely the Chamber of Deputies. The government used to submit proposals for granting assent to ratification first there and then to the Senate.

16 M Shaw, International Law (6 $6^{\text {th }}$ edn, OUP 2008) 44.

17 Rich literature exists on the situation in the United States, but the transferability of the conclusions to states with a continental legal tradition has certain limits.

18 ECPRD is the abbreviation for 'European Centre for Parliamentary Research and Documentation'. The Centre was created in 1977 as an inter-parliamentary network for the exchange of information. It consists of 47 states and several international parliamentary assemblies, and another 4 states have observer status.
} 
inst previous research carried out within the Committee of Legal Advisers on Public International Law (CAHDI) and the British Institute of International and Comparative Law, ${ }^{19}$ or against some other sources.

The first issue concerns the role of individual government bodies (government, parliament, and the head of state) in the ratification procedures of international treaties. The division of powers in the modern state generally implies a scheme of the basic division of functions in expressing the state's consent to be bound by an international treaty: the government concludes the treaty, parliament gives its assent, and the head of state ratifies it. In practice, however, we see different models of these procedures that depend on constitutional, legal and political circumstances, as well as on the historical experience of a particular state. ${ }^{20}$

\section{IV.1 Conclusion of international treaties}

A basic distinction can be found in the contrasting involvement of the head of state and the government in the process of expressing the approval of the state to be bound by an international treaty. On the one hand, there are countries of the so-called Westminster tradition, where the final decision on the international obligations of the state belongs to the head of state (a monarch) practically without any formal (legal) limitation from parliament (eg the United Kingdom or Canada). ${ }^{21}$ Here, the power to conclude international treaties is considered to be the prerogative of the monarch, but the requirement of countersigning the decision of the head of state by a member of the executive branch answerable to the parliamentary assembly significantly limits the traditional concept of the prerogative. ${ }^{22}$ The reverse of this model can be found in states where the power to bind the state is given exclusively to the government (eg Sweden or Japan), and thus the head of state does not interfere in the process of concluding international treaties. ${ }^{23}$ However, these contradictions are merely illusory, because in both these cases of monarchies the will of the government is realised, and in fact the difference consists of whose headed notepaper is used - that of the government or also that of the head of state.

From the point of view of their frequency, both 'extreme' cases are exceptional; in most states there exist certain divisions of power between the head of state and the government in the process of the formation of

\footnotetext{
19 Council of Europe (n 6) VIII.

20 Ibid

21 Responses from A Thorpe, the United Kingdom's ECPRD correspondent (20 January 2010) and V Hooper, the Canadian ECPRD correspondent (14 December 2009). Even in those cases, the head of state may empower another subject, usually a member of the government, to affix a signature.

22 See also Council of Europe (n 6) 25.

23 ibid 26-27.
} 
obligations. It must therefore be distinguished whether the head of state formally has full powers to oblige the state externally (a typical example is the United States of America, but also the Czech Republic), or whether a division of powers to ratify international treaties exists between the head of state on the one hand (usually international treaties approved by parliament), and the government on the other hand. The latter model is described as the most frequent by the authors of the Council of Europe study, and can be found, for example, in Germany, Austria or Italy. ${ }^{24}$

An entirely separate issue concerning the power to conclude treaties arises in federal states, which is mostly related to the division of competences between the units and the federation. The units of federation ordinarily do not possess their own international legal personality. Thus, generally, their participation in the making of international obligations takes the form of approval of the treaty's text by the legislative assembly of the unit before the actual conclusion of the treaty, in the name of the union (thus, it deals with the power to veto the conclusion of an international treaty that is related to the competence of the units of the union). They can possibly also be involved in the process of negotiation through their own acting delegates. ${ }^{25}$ The interests of the units of federation in the intra-national approval of an international treaty can also be protected by the requirement that the international treaty that touches on issues belonging to the competences of the units must also be given approval by the chamber of the parliament in which the units of the federation are represented. ${ }^{26}$

The role of the government, as indicated above, does not substantially differ in models used across various states. In all the countries examined, the government takes part in the initial phases of the conclusion of an international treaty. The reason is that current international politics cannot be separated from domestic politics, which are normally carried out by the government, and the government is also politically responsible for them. In addition, from the practical perspective of ensuring expertise in the process of negotiating international treaties, it is clear that the main role will be given to the civil service operating in central administrative bodies.

From the comparative point of view, the position of ministries of foreign affairs is particularly interesting. In comparison with their Czech counterpart, which, in the process of concluding international treaties,

\footnotetext{
24 ibid 20. Interestingly, the authors from the European Council classified the Czech Republic as a country belonging to this category. With regard to art 63 para 1 lit b) of the Czech constitution, it is, however, inaccurate: according to the constitution, the power to conclude international treaties is vested in the president, who can nevertheless transfer this power to the government or its individual members.

25 Council of Europe (n 6) 20, 35ff.

26 As is the situation, for example, in Germany and Austria - see hereinafter for details.
} 
to a large extent has a co-ordinating and methodical role, the ministries of foreign affairs of some other states (Georgia, ${ }^{27}$ Macedonia ${ }^{28}$ ) are fully responsible for the formal requirements of the treaty before its signing. These latter states also take responsibility for the submission of a ratification bill (or some other method of approval of the international treaty) to parliament. A traditionally strong position is also held by the ministry of foreign affairs in the states of the Westminster model. ${ }^{29}$

\section{IV.2 Approval of international treaties}

The government may likewise act as a body expressing consent with an international treaty on behalf of the state. This power may arise directly from the constitution or it can be delegated by the head of state. Constitution-based power to express consent to an international treaty is characteristic, for example, of the Federal Republic of Germany, where the juridical institute of so-called administrative agreements ${ }^{30}$ exists. They concern treaties not affecting the political issues of the Federation (Bund) and especially that do not require a federal law for their implementation. ${ }^{31}$ On the other hand, it is important to stress that, in addition, these treaties are internationally binding on the Federal Republic of Germany as a whole, not only its public authorities. ${ }^{32}$ The main difference between 'governmental' and 'ministerial' treaties in the Czech Republic rests on separate constitutional power to conclude such international treaties by the public administration. This can have practical relevance when the head of state decides to reassume power to conclude a particular treaty, even of a governmental nature. It is obvious that such an approach would be inconceivable in a model based on the constitutional classification of international treaties.

In France, we can also find administrative agreements (arrangements administratifs), although these are not treaties under public international law, but arrangements among ministries dealing with technical or administrative issues falling exclusively under their competence. ${ }^{33}$

\footnotetext{
27 Response of J Lazarevska, the Georgian ECPRD correspondent (25 December 2009).

28 Response of N Getia, the Macedonian ECPRD correspondent (21 December 2009).

29 Council of Europe (n 6) 34

30 Art 59 para 2 last sentence of the Basic Law of the Federal Republic of Germany.

31 B Kempen 'Commentary on Art. 59 of the Basic Law' in H von Mangoldt, F Klein, Ch Starck (eds), Das Bonner Grundgesetz. Kommentar ( $4^{\text {th }}$ edn, vol 2, Verlag Franz Vahlen 2000) 1875.

32 ibid.

33 These technical arrangements are made in order to specify the existing international treaties or for the purpose of the limited cooperation of the administrative bodies - see Council of Europe (n 6) 22. In Czech law, the category of administrative or technical agreements that would be binding and at the same time would not be approved as international treaties does not exist. In international forums, many documents are labelled as such in order to facilitate the process of their approval.
} 
The role of parliament in the comparative perspective is basically similar, which follows from the fact that these states belong to parliamentary democracies, where a division of powers exists, among other things, between law-making and the executive branches. The involvement of parliament is therefore important, not only regarding the expression of lawmaking competence in a state which is being weakened by international treaties concluded by the executive that has priority over the laws, but also concerning the expression of the supervisory function of parliament vis-à-vis the executive power. ${ }^{34}$

In most cases, the form of approval of international treaties in other states differs from the methods of approval in the Czech Republic. International treaties are predominantly approved by a ratification law, to which, in principle, rules related to the adoption of laws apply. An arrangement similar to the one in the Czech Republic, where parliament expresses approval of an international treaty in the form of a resolution, can also be found in Slovakia. ${ }^{35}$

This fact also has a substantial influence on the consequences of a lack of approval for the domestic ratification of an international treaty by one of the chambers of parliament in bicameral systems. In these circumstances, the ECPRD correspondents were asked whether, in the case where one chamber rejects an international treaty and in the event of a re-vote, it is necessary for the chamber that has already approved the treaty to vote again to approve it.

The general implications of the responses were that, if the approval of an international treaty in parliament resembles the classical legislative procedure (ie the approval of parliament is usually given in the form of a ratification law) one of the chambers normally has a stronger position and can outvote (regularly by a stricter majority) the other chamber, similar to the case of ordinary laws. ${ }^{36}$ If outvoting does not occur after the refusal of the treaty, the ratification process may not proceed. Should the ratification process be reopened, a new proposal must be submitted for consideration in both parliamentary chambers.

An exception to this process was observed by the Belgian correspondent, according to whom in Belgium it is possible in the case of a re-

\footnotetext{
${ }_{34} \mathrm{P}$ Mlsna and J Kněžínek, Mezinárodni smlouvy v českém právu [International Treaties in the Czech Law] (Linde 2009) 222.

35 See art 84 of the Constitution of the Slovak Republic.

36 In Romania, the Senate is this 'stronger' chamber that can outvote the refused proposal for approval of an international treaty in the Chamber of Deputies (response of P Turcu, the Romanian ECPRD correspondent (22 January 2010)), while for example in Austria or Slovenia it is the lower chamber of parliament (responses of I Siess-Scherz, the Austrian ECPRD correspondent (15 December 2009) and J Pajnikhar, the Slovenian ECPRD correspondent (15 December 2009)).
} 
fusal of the proposal by the Senate to resubmit it only to this chamber. ${ }^{37}$ The approval of international treaties in only one chamber is exceptional: an example is Austria. ${ }^{38}$ The exception to the exclusive competence of the National Assembly concerns international treaties governing issues falling exclusively under the competence of the Länder (art 50 para 2 of the Federal constitution) or that change the conventional grounds of the European Union (art 50 para 4 of the Federal constitution). These international treaties must also be approved by the Federal Council (the second chamber of parliament).

A more complicated situation exists in the Federal Republic of Germany, where the procedure following refusal in one of the chambers of parliament depends upon the approval procedure of the particular treaty (according to the content subsumed under the competences catalogue of either the Federation or Länder). In most cases, the first chamber (Bundestag) can outvote the second chamber (Bundesrat). However, for exceptional issues where domestic legislation must be approved by both chambers, an international treaty with similar content must also be approved by both chambers. ${ }^{39}$

\section{IV.3 Role of the head of state in the process of the ratification of international treaties}

The last question posed in relation to the role of the head of state in the process of the ratification of international treaties ran: 'If an international treaty is successfully approved by parliament, is it still legally possible for the head of state to refuse to ratify it, and for this decision to have the character of an absolute veto?'

The responses to this question differed significantly and this clearly depended not solely on the models of the ratification procedures for international treaties in an individual state, but also on doctrinal opinions.

The states in the Westminster tradition stated identically that, with regard to the concept of ratification as a prerogative, the head of state may refuse to ratify an international treaty. Moreover, parliaments do not

\footnotetext{
37 Response of M van der Hulst, the Belgian ECPRD correspondent (9 December 2009). However, the reading of an international treaty in the Belgian parliament commences in the Senate, so resubmission to the Senate is natural.

38 Response of I Siess-Scherz, the Austrian ECPRD correspondent (15 December 2009).

39 Response of K Bartsch, the German ECPRD correspondent (25 January 2010). We are, of course, aware that it might be an overstatement to denote the Bundesrat as a parliamentary chamber. Before the recent reform of German federalism, the ratio of laws requiring the approval of the Bundesrat in federal law-making was predominant - it followed from the expansion of the Federation (Bund) into the competences of the Länder. Now this is returning more to the position foreseen by the founding fathers of the German Basic Law who made provisions for extensive decentralisation.
} 
approve the ratification of a treaty, but currently they only consider the treaty. ${ }^{40}$

In parliamentary forms of governance where international treaties are ratified by the head of state, the predominant opinion was that the head of state is required to ratify the international treaty to which parliament has given consent. Nevertheless, it is useful to structure the issue in more detail.

As stated above, in most states, parliaments indicate approval with ratification in the form of laws on ratification that have a process of approval very similar to the approval process for ordinary laws. As a result, the head of state has the power of veto which is not, however, of an absolute nature, but is only suspensive, which parliament can outvote.

A suspensive veto exists, for example, in Italy; after the entry into force of the law on ratification, the most widespread opinion holds that the president can no longer refuse the ratification of an international treaty. ${ }^{41}$ A similar situation exists in Macedonia ${ }^{42}$ and Lithuania. ${ }^{43}$ In Romania, the president may use a suspensive veto against a ratification act, otherwise he will promulgate a law on ratification within 20 days. According to an explicit constitutional regulation in article 91 of the constitution of Romania, the president must also submit the concluded treaty to parliament within a 'reasonable time limit'. ${ }^{44}$ Similarly, the president in Bulgaria also possesses a suspensive power of veto and if this is outvoted he must ratify the treaty within 7 days. ${ }^{45}$ In Cyprus, there exists a suspensive veto of the president and vice-president (as collectively exercised power). ${ }^{46}$

An interesting regulation exists in Iceland where, if the president refuses a proposed law on ratification, it is not subject to a new appro-

40 Responses of V Hooper, the Canadian ECPRD correspondent (14 December 2009) and A Thorpe, Great Britain's ECPRD correspondent (20 January 2010). But we are aware that exercise of the prerogative is in fact vested in the government; therefore, here the issue deals more with the possibility of the government to withdraw the intent to ratify the treaty concluded than with the discretion of the Crown.

${ }_{41}$ Response of V Striati, the Italian ECPRD correspondent (14 January 2010). But the situation described never happened according to the correspondent and is therefore only a concern of doctrinal legal literature.

42 Response of J Lazarevska, the Macedonian ECPRD correspondent (25 December 2009).

43 Response of E Sinkevicius, the Lithuanian ECPRD correspondent (22 December 2009). The president submits, according to art 84 of the constitution of the Lithuanian Republic, a proposal for the law on ratification to the parliament, which per se indicates his or her positive attitude to the ratification of the international treaty.

44 Response of P Turcu, the Romanian ECPRD correspondent (22 January 2010). The text of the Romanian constitution is available in English on the Romanian parliament's website <http:/ / www.cdep.ro/pls/dic/ site.page?id=371> accessed 24 October 2011.

45 Response of E Kamenova, the Bulgarian ECPRD correspondent (11 January 2010).

46 Response of S Socratous, the Cypriot ECPRD correspondent (9 February 2010). 
val of parliament, but is automatically submitted to a referendum. ${ }^{47}$ In Estonia, should the ratification act be refused and if parliament outvotes the president's veto, the head of state may ask the constitutional court to decide on the issue of ratification. ${ }^{48}$ The Belgian ECPRD correspondent admitted the possibility of a refusal of the ratification of an international treaty by the head of state; nevertheless, with regard to the parliamentary form of governance and the political accountability of the government, it is viable only with the tacit approval of parliament (notably if circumstances change after the approval by parliament of the international treaty). ${ }^{49}$

In Germany, the president may veto a law on ratification if the treaty itself or the domestic regulation connected to it is prima facie contrary to the constitution or to international law. However, according to doctrinal opinion, the president cannot refuse a ratification act solely for political reasons. The president's refusal of the ratification act can be reviewed by the Constitutional Court. Contemporary German doctrine tends to understand that if a law on ratification enters into force, the president is required to ratify the international treaty. Nonetheless, this issue has not appeared before the Constitutional Court as of yet. ${ }^{50}$

In Poland the traditionally strong position of the president exists in the area of foreign relations. According to the prevailing opinion of doctrine, the president has, according to article 133 paragraph 1 of the constitution of the Polish Republic, exclusive power to ratify an international treaty, from which the right to refuse ratification also follows. ${ }^{51}$ The Austrian correspondent expressed a similar outcome: the president has the right, not the duty, to ratify an international treaty. ${ }^{52}$

The situation of Switzerland is specific inasmuch as the government also fulfils the function of head of state. The approval of ratification by a parliamentary chamber at the same time authorises the government to ratify the treaty. However, the government is not obliged to do so if international circumstances change. In practice, it would be unusual for the government to withdraw the intent to ratify the treaty once it submitted it to parliament. ${ }^{53}$

\footnotetext{
47 Response of V Gislason, the Icelandic ECPRD correspondent (19 January 2010).

48 Response of R Kangur, the Estonian ECPRD correspondent (13 January 2010).

49 Response of M van der Hulst, the Belgian ECPRD correspondent (9 December 2009).

50 Response of K Bartsch, the German ECPRD correspondent (25 January 2010). In fact, it is only at the government's discretion to have the treaty ratified, irrespective of the fact that the treaty had been previously approved by parliament - see Ehrenzeller (n 4) 200.

51 Response of W Staśkiewicz, the Polish ECPRD correspondent (8 January 2010). The correspondent makes reference to the commentary of M Masternak-Kubiak, Umowa mięzinarodowa $w$ prawie konstytucyjnym, [International Treaty in the Constitutional Law] (Wydawnictwo Naukowe PWN 1997) 77.

52 Response of I Siess-Scherz, the Austrian ECPRD correspondent (15 December 2009).

53 Ehrenzeller (n 4) 458 and 476.
} 


\section{Regulation of the internal approval of international treaties in the Czech Republic}

The fundamental issues of the conclusion and validity of international treaties are primarily regulated by the norms of public international law. The Vienna Convention on the Law of Treaties of 1969 should be mentioned initially (and the similar Vienna Convention on the Law of Treaties between States and International Organizations or Between International Organizations of 1986, which has not yet entered into force) and also some rules of customary international law. ${ }^{54}$ For the aims of this study, we focus mainly on the internal aspects of the conclusion and approval of international treaties.

The constitution of the Czech Republic, as the fundamental framework of internal law-making procedures, mentions international treaties in only a few provisions related in part to competences, and in part to procedures and effects. This is coupled with the fact that the statutory regulation of the process of the conclusion of international treaties and its internal approval is limited to some phases. These phases consist, in particular, of the laying down of the coordination competence of the Ministry of Foreign Affairs, ${ }^{55}$ the process of the approval of an international treaty in parliament, ${ }^{56}$ and finally the relation to the optional review of constitutionality by the Constitutional Court. ${ }^{57}$ An important regulation on the publication of international treaties is also contained in a separate act. $^{58}$

\footnotetext{
54 For more detail, see, eg, Shaw (n 16) 902ff. The Vienna Convention regulates mainly formal and technical questions connected with the formation of international treaties and the binding effect of their provisions, while it deals with the national consultation only marginally - the exception being, eg, its art 46 para 1, according to which '[a] State may not invoke the fact that its consent to be bound by a treaty has been expressed in violation of a provision of its internal law regarding competence to conclude treaties as invalidating its consent unless that violation was manifest and concerned a rule of its internal law of fundamental importance'. In the Czech Republic, the Vienna Convention of 1969 is part of the legal order published in the official collection of laws as No 15/1998 Coll.

$55 \S 6$ sec. 3 lit. f), g) and h) Act No 2/1969 Coll, on the establishment of the ministries and other central bodies of the public administration in the Czech Republic, as amended.

56 Especially § 108-109 Act No 90/1995 Coll, on the rules of procedure of the Chamber of Deputies, as amended (hereinafter also only RPCD), and § 115 and following Act No $107 / 1999$ Coll, on the rules of procedure of the Senate, as amended (hereinafter also only RPS).

57 Proceedings on the conformity of international treaties under art 10a and art 49 of the constitution with constitutional laws: § 71a-71e Act No 182/1993 Coll, on the Constitutional Court, as amended.

58 Act No 309/1999 Coll, on the Collection of laws and the Collection of international treaties, as amended. Technical issues are elaborated in the Methodical Instructions of the minister of foreign affairs related to the publication of international treaties (hereinafter: Methodical Instruction), available in: Metodická přiručka ke sjednávání mezinárodních smluv [Guidelines for the Conclusion of International Treaties] (Ministry of Foreign Affairs of the Czech Republic 2004) 82-85.
} 
The focus of regulation rests on internal codes dominated by the Directive of the Government on the negotiation, national consultation, application and termination of the international treaties ${ }^{59}$ (hereinafter referred to as 'Directive'). This internal regulation is usually followed by the internal regulations of other bodies involved in the negotiation of international treaties, mainly that of the Ministry of Foreign Affairs.

Internal regulations of the government are, however, preceded by the Decision of the President of the Czech Republic No 144/1993 Coll on the negotiation of international treaties on the basis of which presidential, governmental and ministerial treaties are distinguished according to the body assuming the international obligation on behalf of the Czech $\mathrm{Re}$ public. From this decision alone, it is evident that such a body includes not only the president of the Czech Republic, as could be inferred from the wording of the constitution (see above), but in certain cases also the government or individual ministers.

The decision on the assumption of the obligation, or the confirmation of the assumption of the obligation as the case may be, should nevertheless respect the fact that international treaties do not arise spontaneously, but rather in a deliberate process fulfilling a certain objective. This is generally the cooperation of the Czech Republic with other states or international organisations (possibly with other subjects of international law as well). ${ }^{60}$ Cooperation is realised between the state bodies in charge, and at the same time the application is not separable from domestic procedures where the main responsibility belongs to the government. Since the respective ministries have at their disposal an expert staff for the preparation and negotiation of international treaties, in the current situation it is only theoretically apparent that the president of the Czech Republic would himself carry out his constitutional power to conclude international treaties, ie that he would not delegate it to the government.

Before the commencement of negotiations on an international treaty, it is necessary to examine the goals of the newly proposed regulation and to specify the mandate for negotiations, especially the limits and priorities in the framework of which the negotiations on the wording of the treaty will take place. The Directive for expert negotiations serves this aim. Already before its preparation, the gestor, as the competent ministry, must decide on the important issue of the qualification of the future international treaty under national law that influences, among other things, the national consultation procedure with regard to the Directive. A ministerial treaty is sent only to the Ministry of Foreign Affairs for it

\footnotetext{
59 Approved by the decision of the government of 11 February 2004 No 131.

60 On the theory of the international law of international treaties, see JL Goldsmith and EA Posner, The Limits of International Law (OUP 2005) 83ff; A Cassese, International Law (OUP 2001) $126 \mathrm{ff}$.
} 
to express its opinion; a governmental treaty is sent also to all ministries and the central public administration authorities concerned and, for information, also to the president. Finally, a presidential treaty is sent to all members of the government, to the central public administration authorities concerned, and to the president in order to obtain their opinions, and to the chambers of parliament for their information. Only when there are no substantial objections from the competent bodies may it be adopted by the minister in charge, and at that point negotiations on the text of the treaty may begin.

Once negotiations on the text have successfully concluded, the phase before the signature of the treaty starts when another round of comments by the above-mentioned bodies takes place. In addition, in this phase the proposal for the conclusion of the treaty is sent to the chambers of parliament only for information. ${ }^{61}$ The proposal for the conclusion of the treaty containing the final text of the international treaty, as well as plenty of further appurtenances, is to be approved by the government (with the exception of ministerial treaties where the treaty is approved by the competent minister on the basis of the previous consent of the minister of foreign affairs). In the case of presidential treaties, the decision of the government expressing consent to the conclusion of an international treaty also contains a recommendation to the president of the Czech Republic to authorise the competent person to sign the treaty subject to ratification. ${ }^{62}$ Afterwards, the Prime Minister is authorised by the above-mentioned governmental decision to submit the signed international treaty to both chambers of parliament to approve ratification of the international treaty.

The gestor of the treaty requests the Office of the President of the Czech Republic (via the Ministry of Foreign Affairs) to arrange full powers for a concrete person to sign the treaty (in the case of the signature of a governmental treaty, full powers are signed by the minister of foreign affairs on the basis of governmental authorisation). After the signature of the treaty, the next phase begins - internal approval of the text of the treaty that leads to ratification by the president of the Czech Republic.

61 Despite this rule contained in the Directive, one cannot assume that potential relevantly expressed dissent of one of the chambers of parliament will not have any influence on the subsequent process. On the one hand, the Government also remains politically responsible to the Chamber of Deputies on issues of the conclusion of international treaties; on the other hand, the approval of both chambers is needed after the negotiation of a presidential treaty. The process of formal notice on the negotiation of international treaties listed in art 49 of the Czech constitution (ie presidential treaties) is not much reflected in parliament in the authors' knowledge.

62 The Directive does not restrict the number of persons that can be authorised for signature. Because of possible changes in governmental posts, there is the habit for authorisation not to be connected to a name, but to a function - eg the authorised person is the minister of the interior, not $\mathrm{Mr} \mathrm{XY}$, minister of the interior. However this rule does not apply to ambassadors or other possible plenipotentiaries. 
On the basis of the above-mentioned governmental decision, the Prime Minister sends the treaty (specifically a sufficient number of copies thereof) simultaneously to both chambers of parliament. ${ }^{63}$ The procedure for parliamentary approval of the treaty is governed in detail by the rules of procedure of both chambers; the rule is that, after consultations in the competent committees of parliament, the treaty is approved in a plenary session.

After the signature of the treaty and during the national ratification procedure, or possibly as a part thereof, there may be an optional phase consisting of a review of the conformity of the international treaty with the national constitutional legal order. The procedure in the Act on the Constitutional Court that was, to begin with, far from clear or, more precisely, had a substantially wide-open content, was developed further, mainly by practice in connection with its two decisions on the review of the Lisbon Treaty amending the Treaty on the European Union and the Treaty Establishing the European Community. ${ }^{64}$

Once both chambers of parliament have given their approval for the ratification of the international treaty, and if the procedure for the review of the constitutionality of the international treaty has not been initiated, or if such a review has ended with a decision of the Constitutional Court that the international treaty is not contrary to the constitutional order, it is possible to proceed to the stage of ratification by the president. The ratification instruments must be exchanged in a manner specified in the treaty. If the treaty is nationally negotiated as a presidential treaty, but does not require an exchange of ratification instruments, the Czech ratification instrument is deposited with the archive of the Ministry of Foreign Affairs. When all requirements are fulfilled, the treaty enters into force and is published in the Collection of international treaties.

\section{Selected problems and their possible solutions}

Heretofore we have delineated the rules and explained how the national consultation procedure related to international treaties proceeds.

\footnotetext{
63 Interestingly, the Czech constitution does not state which authority is to submit an international treaty to parliament. From the comparative perspective, it follows that models exist where the treaty is submitted by the head of state - see part III above.

64 Similarly, J Wintr 'První rozhodnutí Ústavního soudu o ústavnosti mezinárodní smlouvy'The First Decision of the Constitutional Court on the Constitutionality of the International Treaty] (2009) 1 Jurisprudence 21-31; Mlsna and Kněžinek (n 34) 481-539; and the articles by J Kysela, V Güttler and J Filip in A Gerloch and J Wintr (eds), Lisabonská smlouva a ústavni porádek $\breve{C} R$ [The Lisbon Treaty and the Constitutional Order of the Czech Republic] (Aleš Čeněk 2009). The Lisbon Treaty, although different in many aspects from classical international treaties, has so far been the only international treaty reviewed by the Constitutional Court in the Czech Republic.
} 
The application of these rules nevertheless causes problems we would like to tackle.

\section{1 Provisional application of international treaties}

The provisional application of international treaties presents a phenomenon that is not unknown in practice, ${ }^{65}$ but is still somehow controversial, since it is based on the application of an international treaty that is not yet in force or binding either on all or on a particular state. This means either that the treaty was signed but the process of national approval has not been carried out, so that the perfect expression of the will of the state to be bound by the treaty is lacking, or that the treaty has not entered into force at the international level (eg because of an insufficient number of ratifications). We should be aware of the difference between the two situations if we reflect on the provisional application mainly from the internal, national perspective; in contrast, from the point of view of international law, this distinction is only of minor importance.

Precisely from the point of view of national law, additional important aspects arise. These include, for instance, the relationship between international and national law, the division of powers and roles between the traditional prerogatives of the head of state or the executive branch at the international level, and at the national level the powers and competences of the legislatures. Can the executive branch oblige the state to apply an international treaty where the constitution requires the approval of parliament in such a situation?

Even after the expression of the state to be bound by the treaty (typically by ratification or by the deposition of the ratification instrument with the authorised depositary), it is not necessary to terminate provisional application according to international law, since it is conceived to operate until the entry into force of the international treaty. The phenomenon most resembling provisional application is that of the anticipated entry into force of an international treaty among the states that accepted it, which overcomes the national issues mentioned above.

With the exception of article 25 of the Vienna Convention on the Law of Treaties (published as No 15/1988 Coll), ${ }^{66}$ which is incorporated

\footnotetext{
65 The provisional application of the treaty concluded in 1840 between the United Kingdom, Austria and Prussia on the one side and the Ottoman Empire (then Ottoman Porte) on the other side is assumed to be the first example of provisional application. See A Geslin, La mise en application provisoire des traités (Editions A Pedone 2005) 6.

${ }_{66}$ Art 25 states: ' 1 . A treaty or a part of a treaty is applied provisionally pending its entry into force if: (a) the treaty itself so provides; or (b) the negotiating States have in some other manner so agreed. 2. Unless the treaty otherwise provides or the negotiating States have otherwise agreed, the provisional application of a treaty or a part of a treaty with respect to a State shall be terminated if that State notifies the other States between which the treaty is being applied provisionally of its intention not to become a party to the treaty'.
} 
in the Czech legal order but is not implemented in further detail, this institute is unknown to the Czech legal order. It is used in the aforementioned governmental Directive whose reach, however, is very limited. If the provisional application of an international treaty oversteps what may be the subject of a decision of the government or of a member thereof (eg organisational changes) within the limits of the laws in force, an explicit national regulation (legal basis) is lacking.

The comparative research based on the resources mentioned in Part III show that the approaches of individual states towards the provisional application of international treaties differ substantially. There are states that fully accept the provisional application of their treaties, while others couple them with certain constitutional limitations (usually limits on interference into fundamental rights), and finally in some states provisional application is completely forbidden.

With respect to the generalisation of an overall approach to provisional application, we assume that the age of the constitutional or statutory regulations in question is more important than the position of individual state bodies within the process of national negotiation and approval: recent legislation regularly contains more detailed provisions on the process of decision-making related to provisional application in a given state. However, it is not possible to conclude on some objective criteria unless these are founded on the longstanding practices of Western European countries vis-à-vis the rather new democracies.

Certain links might be seen in historical and geographical development during the adoption of a new regulation, for example the model of the provisional application of international treaties in Germany, which, in principle, is followed in the Czech Republic, Slovakia, Poland and Hungary. Similarities can also be found in the regulations of some states of the Western Balkans (the consent of the parliamentary committee for international relations in Slovenia and in Croatia). ${ }^{67}$

Another important issue in the provisional application of international treaties concerns their official publication. On the basis of the available resources, such treaties are published in at least the following countries - Estonia, Finland, Spain, Romania (in the latter country all concluded international treaties must be published within 10 days of their signature), Germany and Slovakia. Some states (Norway, the United Kingdom) refer to the availability of the text of the provisionally applied treaties in other (unofficial) sources. Regarding the form of the publication, the notification of provisional application together with publication of the full text of the treaty and the announcement of its entry into force

67 Council of Europe (n 6) 84. 
subsequently in the official collection is the prevailing method. ${ }^{68}$ But in Finland, for example, the text of the treaty is published twice in connection with both occasions mentioned above.

However, a direct link between national regulations on the parliamentary approval of provisionally applied international treaties and their publication in the official collections does not seem to exist. The common feature of the states that have introduced a requirement to publish provisionally applied international treaties is again more often found in modern regulations than in the similar approach to provisional application.

It follows from an international comparison that the Czech Republic should solve at least questions of the national regulation of the termination of provisional application, especially in relation to the role of parliament (see below). The process related to article 25 of the Vienna Convention is not regulated at all (the 'intention not to become a party to the treaty'), while in other states this is the case. ${ }^{69}$ Next, already in the process of negotiating international treaties that might be applied provisionally, the requirement to conform with the national legislation of the parties to the treaty should not be forgotten. Since a provisionally applied international treaty has the nature of valid law in relation to individuals, it should be published in the official collection (one can only follow a law one is aware of). Finally, the requirement concerning the immediate submission of a provisionally applied international treaty for parliamentary approval should be introduced. This follows from the constitutional division of powers among the legislative and executive branches. It would be patently wrong for the executive branch to provisionally apply an international treaty for a long time without allowing the legislature to give it its thumbs up or thumbs down. Such practice would clearly demonstrate a circumvention of parliamentary approval of the ratification of a presidential (see above) international treaty. The refusal to grant approval for ratification by either of the two chambers of parliament should lead to the termination of provisional application. The same effect should be connected to the withdrawal of an international treaty from the procedure of parliamentary approval by the government.

\section{VI.2 Classification of international treaties}

The classification of international treaties includes three sub-issues. The first is the division into presidential, governmental and ministerial treaties (see above), which overlaps with the second sub-issue - identifi-

\footnotetext{
68 As is the regulation in Estonia or Spain.

69 The recently terminated provisional application of the international treaty concerning the processing and transfer of data on certain financial transactions for the purposes of the US Terrorist Finance Tracking Programme - TFTP. For details, see <http://euobserver. com/22/30025> 1 accessed 24 October 2011.
} 
cation of the treaties requiring parliamentary approval for their ratification. The third sub-issue consists of the identification of treaties according to article 10a of the Czech constitution, ie treaties transferring certain powers of Czech public authorities to some international entity.

The assessment concerning which treaties are governmental and ministerial follows from a negative definition: those that do not require the approval of parliament (see article 2 paragraph 2 of the Directive). The concrete assessment of whether a treaty goes beyond the competences of one ministry or not is conducted by the ministry under whose competence the subject matter of the treaty falls; the opinion of the Ministry of Foreign Affairs is here of great significance.

The president of the Czech Republic can also enter into this process by reserving for himself or herself ratification of a treaty in a specific individual case. The consequence of such a presidential reservation is not, however, the submission of the treaty to parliament. Informal consultations in the process of giving comments to the annual overview of international treaties to be negotiated, or in relation to a directive for negotiations on a specific treaty, would rather lead to this effect.

Subsuming a specific international treaty under the categories listed in article 49 of the constitution requiring the consent of parliament for its ratification is not without difficulty. References to previous practice, where applicable in spite of changes in the constitutional text, provide a better orientation. In the event of controversies, the Government Legislative Council fulfils the role of arbiter. ${ }^{70}$

In any event, our focus here is not to clarify the individual categories of treaties, but to place attention on the fact that even this classification is carried out by the government (with the cooperation of the president of the Czech Republic, as the case may be). ${ }^{71}$ In our opinion, the government should not interpret the constitutional catalogue too narrowly, to avoid the danger of circumventing the controlling, legitimising and law-making

70 P Mlsna 'Ústavní aspekty zastupování ČR navenek prezidentem republiky' [Constitutional Aspects of the External Representation of the Czech Republic by the President of the Republic] in V Šimíček (ed), Postaveni prezidenta republiky v ústavním systému České republiky [The Position of the President of the Republic in the Constitutional System of the Czech Republic] (Mezinárodní politologický ústav 2008) 214.

${ }^{71}$ The dominance of the government is also illustrated in the dispute about the assessment of the so-called Irish guarantees attached to the Lisbon Treaty, either as agreements of a political nature or as explanations of the treaty provisions. The government - despite the president of the Czech Republic - followed the latter variant, ie declared the guarantees to be a governmental treaty. See Mlsna and Kněžínek (n 34) 227-228; J Syllová 'Právní charakter irských záruk a ukončení ratifikace Lisabonské smlouvy prezidentem republiky' [Legal Nature of the Irish Guarantees and the Completion of the Ratification of the Lisbon Treaty by the President of the Republic] (2009) 3 Časopis pro právni vědu a praxi 203-210; L Pítrová 'Irské a české záruky sjednané v Lisabonské smlouvě' [Irish and Czech Guarantees Negotiated in the Lisbon Treaty] (2010) 1 AUC - Iuridica 91-92. 
function of parliament. This is in line with the practice between the World Wars when, in case of doubt, the preference was for the international treaty to be submitted to the National Assembly (the equivalent then of parliament). ${ }^{72}$ The presidents of the foreign committees of both chambers are already informed of the intentions of the government in the process of negotiating presidential treaties, which could serve as a basis for potentially more extensive consultations on the regime of a specific international treaty. Nevertheless, the constitutional safeguard consists initially of the construction of article 10 of the Czech constitution, according to which only international treaties that were ratified with the approval of parliament may have priority over statutes. The government is therefore motivated not to bypass parliament, at least in the case of self-executing treaties.

In relation to the third sub-issue of this topic, we are not overly concerned with identifying treaties belonging to article 10a of the constitution, which is considered to be an open topic, as was indicated by the dispute on the assessment of the nature of the Protocol on the revision of the number of deputies in the European Parliament. Rather, ${ }^{73}$ we focus on the role of parliament. In our opinion, the chambers of parliament are bound by the assessment carried out by the government. This is so since it is the only way to avoid a repetition of the conflicts arising before the adoption of the so-called Euro-amendment of the constitution in relation to the treaties on fundamental rights, ie possible divergence in the assessment of the treaty by each of the chambers. If we are to avoid discussions on whether approval of ratification was validly given at all, or disputes on the effects of such treaties, we must decide on the sole centre of assessment. The chambers of parliament can, of course, refuse the assessment of the government by expressing that they would not approve the ratification under these circumstances, or they would in fact reject it. On this basis, trilateral negotiations between the government and both chambers would take place.

\section{VI.3 Repeated submissions of a proposal on the expression of con- sent with the ratification of an international treaty by the cham- bers of parliament}

It is useful to structure the issue of the repeated submission of a proposal to express consent for the ratification of an international treaty in two groups: a) the situation where none of the parliamentary chambers

\footnotetext{
72 E Sobota, J Vorel, R Křovák, A Schenk, Československý president republiky. Státoprávní instituce a jeji život [The President of Czechoslovakia. The Institution in the Theory of State and its Life] (Orbis 1934) 346.

${ }^{73}$ In principle, it deals with the issue whether all changes in the Lisbon Treaty are subject to qualified approval or only those that transfer the powers of the Czech public authorities.
} 
grants approval for the ratification of the international treaty; b) where one chamber gives approval for ratification, but the other does not.

The reasons why a chamber does not grant approval may differ: a repeated practice exists where the government withdraws a proposal in apprehension of a refusal, so that the hearing in the chamber does not continue. ${ }^{74}$ The chamber of parliament may refuse to grant its approval for ratification, or there will not be enough votes to express approval. ${ }^{75}$ In the Chamber of Deputies, another circumstance can be added: in relation to the end of its term, the hearings of all bills terminate and they must - in the case of concern or necessity - be resubmitted to the newly established Chamber of Deputies. ${ }^{76}$ Another way for refusing consent, stated by $\mathrm{P}$ Mlsna and $\mathrm{J}$ Kněžinek, is the revocation of the already given approval up to the moment of ratification. ${ }^{77}$

The latter situation has not happened yet, and we consider it at least questionable: in our opinion, an international treaty leaves open the sphere of the executive branch only for the process of expressing approval, as, once this approval is given, the chamber has nothing more to dispute, since the treaty is at the disposition of the government. The 'revocation of approval' could also interfere with the review of the treaty by the Constitutional Court, because the filing of submissions by groups of deputies or senators is limited to the period between the expression of approval by the chambers of parliament and the ratification itself - the revocation of the approval would make problematic not the submissions, but rather the continuation of the judicial review, which would thus in all likelihood have to be terminated.

In the first of the examples mentioned above, doctrine and practice jointly state that, after rejection in both chambers of parliament, the government may resubmit the treaty for approval. A general rule can

\footnotetext{
74 There were three cases in the 5th electoral term of the Chamber of Deputies (20062010): the Agreement between the European Union and the United States of America on the processing and transfer of passenger name record (PNR) data by air carriers to the United States Department of Homeland Security was withdrawn from both chambers and then resubmitted. In contrast, two agreements with the USA concerning the establishment of a radar military base in the Czech Republic were withdrawn only from the Chamber of Deputies (Chamber of Deputies Bills No 621 and 622), while they were approved in the Senate (Senate bills No 333 and 334) - available at <www.psp.cz> and <www.senat.cz> accessed 24 October 2011.

75 This situation is very rare - eg the refusal to grant approval for ratification of the Convention on the Protection and Promotion of the Diversity of Cultural Expressions at the $9^{\text {th }}$ session of the $6^{\text {th }}$ functional term of the Senate on 30 October 2009 (Senate bill No 103).

76 After the end of the $5^{\text {th }}$ electoral term of the Chamber of Deputies in 2010, a total of 19 international treaties were left without the expression of approval by this chamber - see $<$ http://www.psp.cz> accessed 24 October 2011.

77 The cited authors admit the possibility of the revocation of the granted approval with reference to older literature - Sobota, Vorel, Křovák, and Schenk (n 72) 351-352; Mlsna and Kněžinek (n 34) 233.
} 
be inferred from this: the refusal of a proposal for ratification does not automatically lead to an absolute obstacle for a repeated future hearing of the same unchanged treaty (a change in the international situation, a different composition of the chambers, etc).

A more difficult situation occurs in the case where one of the chambers gives its approval to ratification while the other does not, either because it did not vote or because the vote did not conclude with the granting of approval. We can then ask whether, in the case of persistent interest in gaining approval for ratification, the government must resubmit the treaty again to both chambers or only to the one that has not given its approval. The practice has not been unified in recent years, mostly due to the insufficiently coordinated will of the government, but partly also because of the changes and differences in opinion of the parliamentary chambers; there have not been a significant number of such cases according to the information available. ${ }^{78}$ In the present electoral term, the government resubmitted all treaties that had not been voted on in the previous term of the Chamber of Deputies to both chambers, even if the Senate had already given its approval for ratification.

According to some, the decisions of the chambers do not cease to be valid in the next electoral term in general, although the question remains whether the power of the government to submit first an international treaty to either of the chambers also allows for its submission in a different electoral (functional) term. This could even relate to different governments. We can ask whether, in the case of a lapse of several years between readings of a proposal for the approval of ratification in each of the chambers, this would amount to bypassing the institute of parliamentary approval: should we consider as a valid approval one given by the chambers with a ten years' interval between them? Such an interpretation would allow the government to speculate on the submission of a proposal to individual chambers. Moreover, if the government postpones submission until the composition of one of the chambers changes favourably (typically the Senate, since a particular government does not outlast the electoral term of the Chamber of Deputies), the ratificati-

78 For example, agreement between the government of the Czech Republic and the United Nations for the Loan of Prison Staff to the International Criminal Tribunal for the Former Yugoslavia was submitted to the chambers of parliament in April 2006. The Chamber of Deputies did not hear the proposal before the elections (Chamber of Deputies Bill No 1286), while the Senate gave its approval of this treaty in October of the same year (Senate Bill No 337). The proposal in question was resubmitted by the government only to the Chamber of Deputies (Chamber of Deputies Bill No 79). The Convention on the Physical Protection of Nuclear Material had nearly the same destiny (the Chamber of Deputies did not cast a vote before the elections, while the Senate had given its approval for ratification), but in 2007 the government resubmitted the treaty to both chambers (so that the Senate gave its approval twice). The authors wish to thank Dr D Bèlinová, director of the legislative section of the Office of the Czech Senate, for these examples. 
on process could be quite prolonged. The settled constitutional practice wherein, since 2003, the Government submits proposals for the approval of ratification to both chambers simultaneously is also of importance, since it could indicate the existence of a constitutional custom. ${ }^{79}$

Reflections on the internal approval procedure lead to an understanding of the whole process of ratification as being composed of individual phases, and the approval of both chambers is one of them - in particular after the phase of the submission of an international treaty by the government and before its ratification by the president of the Czech Republic. Repetition of the act of the ratification process should take place within these phases, ie when approval in one of the chambers is not reached, it should lead to the resubmission of the treaty to both chambers (similarly, the refusal of ratification by parliament does not necessarily lead to renegotiation, ie to the opening of the text of the treaty. Therefore, it does not interfere with the first 'governmental' phase).

One could cautiously argue with the above opinion, mainly along the lines that the approval of parliament is not explicitly bound by time limits or terms, and secondly, it could seem fairly strange to require one of the chambers that has already expressed its approval to give it again for a second or third time only because the other chamber has objections against the treaty.

It seems to us that the only subject of easy codification is the simple requirement for the approval of both chambers based on the same submission. The reflection of the passing of time (the scope of the functional and electoral terms and their overlapping) and the differentiation between the lack of approval because no vote was taken, due to an insufficient number of favourable votes for approval for ratification, or because the government withdrew its proposal, would make any explicit regulation difficult, even unclear. However, we consider both ways to be in principle in conformity with the Czech constitution.

The tendency towards a more difficult way would be resolved by a decision of the president of the Czech Republic upon the ratification of a specific treaty, rather than by a general rule. From the point of view of constitutional law, the president's act of ratification presumes confirmation of the proper internal ratification process. The president is not obliged to ratify an international treaty when he states the defects he has observed in the national process of expressing approval.

\footnotetext{
79 It is, however, disputable, because this practice was initiated by a decision of the government that can obviously be changed. The parallel or subsequent (variably or in a fixed order - in the Czech Republic priority was held by the Chamber of Deputies until 2003, in Belgium it is the Senate) submission of a treaty does not resolve the problem of the repetitiveness of the acts: does the disapproval of the second chamber in the process make the approval of the first chamber invalid'?
} 
Therefore, should the president of the Czech Republic find deficits in the process of approving an international treaty (consent was given during different electoral terms, consent was given on the basis of proposals set at a different time by the government, etc), he would probably trigger negotiations in order to remedy unconstitutionality. If the government or one of the parliamentary chambers insists that approval be given in conformity with the constitution, the subsequent process could lead to a conflict of competence before the Constitutional Court, according to article 87 paragraph 1 lit k) of the Czech constitution.

\section{VI.4 Simplified parliamentary approval for the ratification of pre- sidential treaties?}

According to some, traditional constitutional requirements for the expression of parliamentary approval for international treaties in some cases no longer satisfies current levels of international cooperation. ${ }^{80}$ An example may be the regulation of certain issues in an international treaty that would otherwise, in purely national terms, require only regulation at the level of implementing legislation. Other examples could include cases that need a flexible reaction, and any waiting for the approval of parliament could endanger the fulfilment of the aim of the treaty. The question is how to balance the competing claims of rapidity and flexibility with the traditional roles of parliament.

In the first place, it is necessary to point out the possibilities arising directly from international law. Not every treaty requiring ratification, in the view of international law, requires the consent of parliament, even if this is often called 'ratification'. ${ }^{81}$ This is also the reason why in some cases the terms 'acceptance' or 'approval' (see article 14 of the Vienna Convention on the Law of Treaties) are preferred. ${ }^{82}$ Another possibility is to conclude a formally non-binding memorandum of understanding that can serve as the basis for the unification of national practices which at the same time demand lower requirements in the case of modification or termination. ${ }^{83}$ In practice, the combinations of other mechanisms for the modification of existing treaties, connected, for example, with the requirement of a qualified majority and a certain number of expressions

\footnotetext{
80 I Seidl-Hohenveldern, Mezinárodni právo veřejné [Public International Law] ( $3^{\text {rd }}$ edn, ASPI 2006) 53.

81 Thereby we can identify ratification required both by an international treaty and a constitutional regulation, ratification insisted on by the treaty even if not required by national constitutional rules, 'internal' (small) ratification following art 49 of the constitution no matter if the parties to a treaty are not interested in it, and the below-mentioned subsequent ratification of a treaty that was not originally subject to the reservation of parliamentary approval.

82 A Aust, Modern Treaty Law and Practice (CUP 2000) 87.

83 In general, see ibid $26 \mathrm{ff}$.
} 
of the contracting parties to be bound by the change, are used as well. ${ }^{84}$ However, none of these methods can be applicable in the specific case of a multilateral treaty when one state is not able to persuade the others of the use of a certain form because of the possible complications in this state's national ratification process.

Moreover, irrespective of its name, every agreement must be assessed according to its content, according to Czech law. This brings to the fore the issue of the interpretation of the reach of article 49 of the constitution, which lists the treaties subject to parliamentary involvement in the form of a decision (in principle a simple majority in both chambers, but in the case of the transfer of competences a three-fifths majority is required).

Another question could be whether, in the situation where the chambers of parliament gave their approval for the ratification of an international treaty, such an approval is necessary for every treaty modifying the original one. In our opinion, the competence of parliament is given precisely with regard to the list of treaties in article 49 of the constitution, ie the content of the change is decisive. This material criterion can be completed by the formal criterion based on the principle of procedural equivalence according to which the modifications of an act are subject to the same procedure as the original act itself.

The issue of the modifications to treaty annexes of a technical or administrative character (lists of chemical substances or animals, etc) is to some extent specific. In particular, the Ministry of the Environment has under its competence a number of treaties containing, for example, annual quotas for permitted whale hunting, changing the lists of chemical substances, etc. It often happens that the Czech Republic does not manage to ratify the changes to an annex within a year, and another change is concluded in the meantime. Even if we overlook the fact that the delay is not caused in the parliamentary or presidential phase of the ratification process, but in the government, this separate issue could be solved on the basis of the concept of delegation. Together with approval of the ratification of a treaty that presumes the simplified change of its technical annexes (if their content does not fall within the catalogue in article 49 of the constitution and they are not self-executable), the parliamentary chambers would express their consent that such changes be approved by the government. ${ }^{85}$ Modification of the annexes must be sent

\footnotetext{
84 The opt-out variants are also applicable when, for the modification of a treaty, it is sufficient that a required number of states agree with the change and others must expressly notify that they do not want to be bound by such a modification. The changes adopted by majority voting are foreseen by some founding treaties of international organisations. On other methods, see, eg, Aust (n 82) $216 \mathrm{ff}$.

85 In a slightly different situation, Ehrenzeller explains that the importance of the subject matter should correspond with the procedure - see Ehrenzeller (n 4) 83. Through consent with the delegation, we can read, for example, the specific procedures diminishing the
} 
to both chambers for information so that supervision on the use of delegation is guaranteed. The way described above can be examined even without amendments to the rules of procedure of the chambers, either by direct testing or through more detailed directives implementing the parliamentary chambers' rules of procedure.

A similar situation could exist with the president of the Czech Republic: once he or she is allowed to transfer the conclusion of treaties not requiring the approval of parliament to the government, he or she could in fact do the same in the case of the aforementioned technical annexes. In this instance, the president would have also ratified a treaty, aware of the simplified approval procedure provisions contained therein. Nevertheless, even if all participants of the ratification procedure reach consensus, the decisive role connected with the application of the changes in the technical annexes belongs to the courts, should they be confronted with the question of whether the consent of parliament in the form of a delegation fulfils the requirements for the domestic application of the treaty and its changes. In any case, we consider this route for the approval of international treaties to be in conformity with the constitution.

Besides this technique of simplified amendments, the fast-track procedure in the parliamentary chambers that are provided for in the rules of procedure should be given prime consideration.

\section{VI.5 Ratification}

The problem of the ratification of international treaties has been mentioned several times before. The main bone of contention related to the ratification procedure in the Czech Republic is the question of whether the president of the Czech Republic acts as an independent decision-maker with unfettered discretion, despite being limited by the condition of counter-signature. ${ }^{86}$ There is an alternative position, according to which the president is merely the formal bearer of competence, but it is

need for a direct change of the treaty text in the Lisbon Treaty, ie the bridging clauses and the flexibility clause. This is roughly the view of the government presented in the opinion submitted before the Constitutional Court; the court had not, however, explicitly followed this view. Nevertheless, this particular example does not fit with Ehrenzeller's comment quoted above; therefore, one cannot be surprised by the compensation of the consequences of these clauses by many parliaments.

86 Probably the most complete conception can be found in the article by Z Koudelka 'Prezident a mezinárodní smlouvy' [The President and International Treaties] in Conference Proceedings Days of Law 2009 (available at <www.law.muni.cz/edicni/dny_prava 2009/> accessed 24 October 2011). An earlier version of this article was published in $Z$ Koudelka (2009) 9 Právník 929. The list of works by other authors maintaining the same position is summarised by R Malenovský, who himself maintains the opposite position - see R Malenovský 'Může prezident republiky odmitnout (odložit) ratifikaci mezinárodní smlouvy?' [May the President Refuse (Postpone) the Ratification of an International Treaty?] (2009) 22 Právní rozhledy 812 . 
the government which determines the content of its use. This position is based on the context of the parliamentary form of government, in which the policy of a state, including its foreign policy, is operated by the government which is responsible to parliament. Other reasons include the lack of the legal responsibility of the indirectly elected head of state and the inclusion of this competence among the competences requiring counter-signature. We do not dispute that it is the president's hand that holds the pen that signs the acts within his or her competence. The disputed fact is whose will it is that moves the hand. The president, indirectly elected and exempt from legal responsibility, is subject to limitations in the parliamentary system. However, a directly elected president would not be subject to such limitations in a semi-presidential system, and this even if the catalogue of competences remained the same. Paradoxically, this could mean greater liberty in the exercise of the president's competences in cases where the decision is subject to review (eg vetoing a bill) and, vice versa, greater self-restraint if the president's decision is final.

The decisive factor in this debate is whether the president's decision on the ratification of an international treaty is subject to the counter-signature of the prime minister or a competent member of the government. In the academic discussions which took place in Czechoslovakia between the World Wars, opinion crystallised according to which the necessity of counter-signature leads to the requirement for the harmonisation of wills of both co-signatory bodies. However, in the $20^{\text {th }}$ century, the construction was eventually recognised according to which the monarch in a parliamentary form of government, or generally the head of state in a parliamentary system, formally executes an act, but the content of the act or the fact whether the act is executed lies in the hands of the responsible government or the responsible minister. In short, the will of the politically responsible agent outweighs the will of the agent who is not politically responsible, according to the maxim of the relationship between power and responsibility (ie, more power leads to more responsibility and vice versa), so that the head of state who is not politically responsible in principle cannot defy the proposal of the responsible minister. ${ }^{87}$

This is, of course, a rather simplified scheme from which there are many exceptions, usually derived from the current conditions (the power or prestige of the concrete head of state, political weakness of go-

\footnotetext{
87 J Krejčí Problém právního postavení hlavy státu $v$ demokracii [The Problem of the Legal Status of the Head of State in a Democracy] (Moderni stát 1935) 56 and 68. Very significant are the words 'in principle', because they exclude unexceptional duty. The integrating and guaranteeing role of the head of state is thereby secured. The head of state thus acts as a corrective of governmental policy, rather than the government correcting the acts of the head of state.
} 
vernments, fragmentation of parliaments, etc). ${ }^{88}$ If we scrutinise more carefully the roles of heads of state, we find that one single type of conduct of head of state does not exist; in fact, we rather see several typical roles or 'faces'. 89

The above-mentioned framework implies an understanding of ratification as the formal completion of national consultation and approval of an international treaty, rather than an act of unrestricted discretion by a head of state, whether he or she assumes the international obligation or not.

This reflects the interpretation of C Schmitt, even though his work is based on the Weimar constitution, but of course in the proper historical and international context. ${ }^{90}$ The Weimar constitution conferred the conclusion of international treaties on the President of the Empire, though the ratification of some international treaties was subject to the consent of the Parliament of the Empire. The regulation was similar to that of the 1871 constitution, in respect to which G Jellinek noted that the Emperor should assume only such obligations that he is able to fulfil, ie where he may count on the consent of the Parliament of the Empire. ${ }^{91}$ Schmitt adds that refusal to ratify was considered something abnormal, almost an offence towards the other contracting state, until the reservations of parliamentary consent or consent by referendum occurs. Since that time, refusal to ratify an international treaty due to the refusal of parliamentary or popular consent is not considered exceptional at all. ${ }^{92}$ The same implies that refusal to ratify an international treaty without the fulfilment of a specified condition remains abnormal, especially in the case of the head of state who concludes the treaty or authorises its conclusion.

The role of the president of the Czech Republic as a body ratifying international treaties has furthermore changed after the 'Euro-amendment' of the Czech constitution, due to the new roles of parliament and the Constitutional Court. In the past, when subsequent legislative acti-

\footnotetext{
88 The basic and, in the era before the judicialisation of constitutional law, the only coercive instrument in relation to the head of state is the threat of demission. If the minister or the government does not intend to resign, the only effect of the refusal of the head of state to decide is the absence of a decision. If an alternative government exists to replace the former, the head of state may contribute to demission if there is an expectation that the new government would be more willing to co-sign the decisions that the head of state makes.

89 See, eg, J Wintr 'Prezident republiky jako reprezentant státu, garant ráa du a moderátor politických sporů' [The President of the Republic as a Representative of a State, Guarantor of Order and Moderator of Political Disputes] in Šimíček (n 70), or V Bogdanor, The Monarchy and the Constitution (Clarendon Press 1997).

90 C Schmitt, Verfassungslehre (9 $9^{\text {th }}$ edn, Duncker \& Humblot 2003) 269-271.

91 G Jellinek, Gesetz und Verordnung (Paul Siebeck 1887) 349, 354.

${ }_{92}$ C Schmitt (n 90) 269.
} 
vity was necessary, consent for the ratification of an international treaty creating an international obligation of a state was given by parliament as a controlling body of the executive. After the entry into force of the 'Euro-amendment' of the Czech constitution on 1 June 2002, the additional requirement for the transformation of international treaties into the Czech legal order has been no longer necessary. Parliament nowadays acts as a norm-creator when voting on an international treaty, since it decides on the treaty as a future part of the Czech legal order. We do not claim that 'consent' means 'command', but the character of the consent has of necessity changed.

The situation is even more evident when taking into account the preliminary review of the constitutionality of international treaties. In the absence of this procedure, it was the president of the Czech Republic who had to assess their constitutionality. If it is now the Constitutional Court that is called on to review constitutionality, and the extent of the president's possible reservations is decreasing. ${ }^{93}$

Even though we presume that the president has in principle a duty to ratify an international treaty, ${ }^{94}$ certain conceivable situations may appear in which the ratification would cease to fulfil its function (eg significantly worsened relations with the contracting state). Even in these situations, the president would not remain solitary, ie without the government's opinion. It is self-evident that most likely neither of the two presidents of the Czech Republic (V Havel and V Klaus) held the position that it is the president's duty to ratify international treaties. Because parliament and the government remain reluctant to 'force' the president, either through official statements or through legal actions, to ratify international treaties, it can thus be concluded that interpretation of this competence remains unclear.

\section{Observations regarding the 'European' Treaties}

Concerning the international obligations of the Czech Republic and other EU Member States arising out of international treaties (apart from international treaties to which the states are contracting parties), the si-

\footnotetext{
93 The president of the Czech Republic may not refuse to ratify an international treaty only for the reason of alleged unconstitutionality. See P Ondrejek 'Role prezidenta republiky při sjednávání a ratifikaci mezinárodních smluv' [The Role of the President of the Czech Republic in the Process of Negotiation and Ratification of International Treaties] (2009) 1 Jurisprudence 53.

94 This opinion was also expressed by the notable Czech expert J Malenovský in 'Kulečnik namísto štafetového běhu' [Billiards instead of the Relay Race] (2009) 4 Právní rozhledy, and this opinion was also held by the Czech Constitutional Court in the form of obiter dictum in the so-called second ruling on the Lisbon Treaty (Ref No Pl ÚS 29/09) available at $<$ http://nalus.usoud.cz> accessed 24 October 2011.
} 
gnificance of international treaties concluded by the European Union (or the European Community before the entry into force of the Lisbon Treaty) cannot be ignored. These treaties are binding on the Member States and their importance rises in proportion to the increasing amount of competences which the Member States have conferred upon the Union.

The crucial issue for the enforcement of the Member States' compliance with international obligations concluded by the European Union is the setting of the effects, the consequences of these treaties in the Member States' legal orders (these effects include the direct or indirect effect of the provisions of international treaties in the legal orders of the Member States, and the primacy of their provisions over national law as well as secondary European law). While it is for a state to determine the consequences of international law in its legal order according to the classical doctrine of public international law, in the case of the treaties concluded by the European Union, European law itself determines these effects.

The conclusion of international treaties by the European Economic Community itself was already anticipated in its founding treaty of 1957 (in the framework of the common commercial policy) ${ }^{95}$ At present, the practice of negotiating international treaties goes much farther: the doctrine of implied powers of the Community or the Union has been upheld by the European Court of Justice. ${ }^{96}$ The conclusion often occurs of so-called mixed agreements, which are concluded both by the European Union and by the Member States. The main reason for negotiating mixed agreements is the fact that, in some areas regulated by the agreement in question, the competences of Member States are transferred to the European Union.

The main difference between the mixed agreements on one hand and international treaties under the exclusive competence of the Union on the other does not lie in the process of negotiating the treaty, since it is the European Commission that plays the central role in both examples. The main difference resides in the process of the internal approval of such treaties. Mixed agreements go through the usual approval procedures in Member States as would any other international treaty concluded solely by them (namely, parliamentary approval), whereas treaties concluded under the exclusive competence of the European Union do not.

\footnotetext{
95 Francis G Jacobs 'Direct Effect and Interpretation of International Agreements in the Recent Case Law of the European Court of Justice' in A Dashwood and M Marescau (eds), Law and Practice of EU External Relations: Salient Features in a Changing Landscape (CUP 2008) 14.

96 Paras 15 - 17 of the decision from Case No 22/70 Commission $v$ Council (AETR/ERTA) [1971] ECR 263. For comments on this case, see P Eeckhout, External Relations of the European Union (OUP 2004) 59ff.
} 
Internal consultation procedures in the case of mixed agreements often lead to these agreements including a clause on provisional application, which allows application usually to take effect immediately after its signature. ${ }^{97}$ This conception, however, does not correspond to the traditional function of this institute - to apply an international treaty in exceptional cases before its entry into force, if compelling reasons exist for such application.

The Treaty of Lisbon brought the last (for the moment) setting of the division of competences between the Union and its Member States in the area of decision-making procedures. These have been demonstrated in several aspects in the field of international treaties:

1) the codification of the current case law of the Court of Justice of the EU regarding the competences of the European Union (previously European Community) to conclude international treaties; ${ }^{98}$

2) the increasing role of the European Parliament, which nowadays gives consent to the conclusion of more types of international treaties; ${ }^{99}$

3) with regard to certain policies, where the Council decided by unanimous voting, the decision procedure has been changed to qualified majority voting. ${ }^{100}$

The process of negotiations on international treaties has changed in several other aspects (eg the role of the Union negotiator). But since this goes beyond the examined problems, it is not necessary to mention these issues in this paper. It can be concluded that international treaties with third states concluded by the European Union have been confirmed by the Lisbon Treaty as a general source of European law.

The rising importance of international treaties concluded by the Union logically requires that Member States should be more involved in the process of their negotiation. Even if treaties are concluded under the

\footnotetext{
97 From the facts available on the Council internet pages (<http://www.consilium.europa.eu/App/ accords/default.aspx?lang=EN\&cmsid=297> accessed 24 October 2011), it follows that in 2009 there were 14 international treaties provisionally applied out of 45 concluded treaties (almost one third). If, as Geslin found in her research, out of approximately 33,000 international treaties registered at the UN after 1945, only about 1,000 (3\%) have been provisionally applied (Geslin (n 65) 347), this shows that the conception of the provisional application of international treaties is somehow different in the European Union.

98 This is not only the previously mentioned decision in the ERTA case, but many other judgements, including opinions delivered.

99 The European Parliament obtained competence to co-decide on the conclusion of an international treaty inter alia in the fields where, according to the Lisbon Treaty, it may co-decide within the ordinary or the special legislative procedure - see art 218 para 6 lit a) point v) of the Treaty on the Functioning of the European Union (hereinafter TFEU).

${ }^{100}$ See art 218 para 8 TFEU.
} 
exclusive competence of the European Union, the Commission requires information from Member States in order to make use of them in the process of negotiating similar treaties with other states. ${ }^{101}$

\section{Conclusion}

The above-described pitfalls regarding the expression of the consent of a state to be bound by an international treaty shows that the incomplete constitutional regulation of the procedures for internal approval of an international treaty needs to be supplemented by more detailed regulation contained in the internal regulations of the government or the Ministry of Foreign Affairs, as is the case in the Czech Republic, or directly in the law. No regulation can, however, substitute the consensus of particular state bodies regarding their role in the ratification procedure. Consensus in the Czech Republic does not exist, as was shown in the recent example of the ratification procedure of the Lisbon Treaty.

The prospective revision of internal regulations concerning the conclusion of international treaties in the Czech Republic should, in our view, rather regulate principal questions that could serve as a guideline to resolve various situations that international practice brings.

Attention should also be given to international treaties concluded by the European Union or the Union together with Member States, the significance of which will probably continue to increase. Negotiating such treaties is at present exclusively in the hands of the Commission. Without institutionalised possibilities to control procedures by the bodies of the Member States, the Member States may end up being internationally bound by obligations about which they would find out only after their publication in the Official Journal of the European Union.

${ }^{101}$ Commission, 'Evaluation of EU Readmission Agreements' (Communication) COM (2011) 76 final <http://ec.europa.eu/home-affairs/news/intro/docs/COMM_PDF_ COM_2011_0076_F_EN_COMMUNICATION.pdf> accessed 24 October 2011. 